\title{
Corporate Social Reporting and Board Representation: Evidence from the Kenyan Banking Sector
}

\author{
Dulacha G. Barako \\ Alistair M. Brown \\ Contact: Barako D. G.: BarakoDG@centralbank.go.ke \\ or Alistair Brown: Alistair.Brown@cbs.curtin.edu.au
}

Dr Dulacha Barako is a lecturer at School of Accounting, Curtin University of Technology, Western Australia. Dr Barako has close research relationship with the Central Bank of Kenya on issues of financial stability, and has a deep interest in financial accounting issues of Africa. He recently won the School of Accounting Rising Researcher of the Year Award, and is on the editorial panel of an international refereed accounting journal.

Dr Alistair Brown is Director of Accounting Research at the School of Accounting, Curtin University of Technology and a member of the university's research Digital Ecosystems and Business Intelligence Institute. $\mathrm{He}$ is also on a number of editorial boards of refereed international accounting journals. 


\title{
Corporate Social Reporting and Board Representation: Evidence from the Kenyan Banking Sector
}

\begin{abstract}
The paper examines the influence of gender and board representation on communication of corporate social reporting by Kenyan banks. The descriptive statistical analysis reveals that the level of corporate social disclosure by Kenyan banks is low with a mean of $15 \%$, indicating that disclosure of corporate governance information is not of primary concern to Kenyan banks. In particular, there is a complete lack of disclosure on the categories of Recruitments, Employment of Special Groups, Assistance to Retiring Employees, Employees Productivity and Turnover. The results of multiple regression analysis indicate that board representation can fundamentally improve corporate communication. A higher level of women representation and independent directors greatly improves disclosure.
\end{abstract}




\section{Introduction and motivation}

This paper examines important issues of gender representation, improved corporate social reporting and corporate governance practices in the annual reports of the banks. Specifically, the paper addresses two related research questions: first, what is the extent of Kenyan banks' disclosure of corporate social information in annual reports; and, second, what factors explain the level of disclosure of corporate social information by Kenyan banks.

Within the context of corporate social reporting research, this study is of special importance because of its specific gender, industry and country focus. Prior accounting disclosure research often excludes banking and finance institutions from their sample due to the stringent regulatory requirements associated with this sector (Hossain, Tan, \& Adams, 1994, Ismail \& Chandler, 2005, Khalid, 2005, Leung \& Horwitz, 2004). This paper seeks to fill this gap by providing an insight into corporate social reporting practices of this vitally important sector. Importantly, this study also focuses on Kenya, and in the broad context of developing country studies, contributes to the growing number of empirical disclosure research on the developing economies (Barako, Hancock, \& Izan, 2006, Khalid, 2005, Owusu-Ansah, 1998). While it is always difficult to generalise the findings of one specific country to others, this Kenyan- specific study is important in that it adds to the accumulation of developing country knowledge about corporate social reporting (Brown, Purushothaman, Scharl. and Astami, 2007) 
The remainder of this paper is organised as follows. Section 2 documents the corporate governance and corporate social reporting environment in Kenya. Section 3 discusses the theoretical framework and literature review, while Section 4 outlines with the research design. The research findings are reviewed in Section 5. The final section highlights the implications of the results.

\section{Corporate governance and corporate social reporting 1}

Since the focus of this research is on social reporting, it is appropriate to provide a brief overview of the regulatory framework in the Kenyan context. The Kenyan Companies Act sets the general framework for corporate financial reporting. The pronouncements by the Institute of Certified Public Accountants (ICPAK) supplement the requirements of the Kenya Companies Act.

To date, in the Kenyan context, corporate social and environment reporting is voluntary. The Centre for Corporate Governance (CCG) Kenya is the main driving force with respect to corporate governance reforms in Kenya. The Centre was established in 1999, and also serves as serves as Secretariat to the Pan African Consultative Forum on Corporate Governance. In 2005 CCG

\footnotetext{
${ }^{1}$ For further details on corporate governance and corporate financial reporting environment in Kenya see Barako et al. 2006.
} 
issued guidelines on corporate financial reporting and disclosure. For companies, adoption of the guidelines is voluntary. The guidelines made reference to corporate social reporting as follows:

...disclose in summary the nature of the enterprise's social responsibility and corporate citizenship activities, environmental, occupational health and safety, and workforce management policies and practices, and whether the enterprise has in place a code of ethics, and the general level of adherence to this code (The Centre for Corporate Governance, 2005)

Given the voluntary nature of corporate social reporting, it is not surprising that in a survey of governance practices in the banking sector The Centre for Corporate Governance (2004) note that “only 3 banks have corporate social responsibility programmes" (p.47).

In terms of governance, women's participation is very low. In this respect The New Partnership for Africa's Development (NEPAD)² under the African Peer

Review Mechanism (APRM) country report for Kenya states:

...evidence of gender marginalisation in the country is that women remain vastly under-represented...women in Kenya comprise a majority, accounting for 42 percent of the population and 65 percent of the country's registered voters. Although the current government has appointed more women to cabinet and nominated more women to parliament than previously done, the numbers are still dismal [3/26] Women Cabinet Ministers, [4/39] Assistant Ministers, 6/25 Permanent Secretaries, 18/222 Members of Parliament, 0/8 Provincial Commissioners, 2/71 District Commissioners and 8/57 Judges(African Peer Review Mechanism, 2006) (APRM 2006, p. 22 and 109).

2 NEPAD is new initiative undertaken by African countries to address the challenges facing the continent such as, poverty, underdevelopment, peace and security. For further details see http://www.nepad.org/. APRM is a mutually agreed instrument to assess a member country on a number of socio-economic fronts. 
It is against this background that gender is the main thrust of board diversity examined in this study with respect to corporate reporting practices.

\section{Literature Review and Hypotheses Development}

Stakeholder theory posits that an entity strives to harmonise its activities with stakeholder expectations through the communicative channel of corporate social reporting. Stakeholder theory may be divided into managerial (positive) and ethical (normative) branches (Deegan, 2000). The managerial branch posits that managers will be influenced by the powers of particular stakeholders on the business activities of an organisation (O'Dwyer, 2002). Under the managerial branch of stakeholder theory, key stakeholder demands are given considerable weight by managers when generating corporate social reports. Thus, in the Kenyan banking context, we might expect core-financial stakeholders (for example, investors, creditors and shareholders) having considerable influence over banks' actions and reporting.

The ethical branch of stakeholder theory argues that all stakeholders have rights to fair treatment, regardless of how distant or close the stakeholder is to the business (Deegan, Rankin, \& Voght, 2000). Conveying information to satisfy the needs of all stakeholders is, of course, difficult but the ethical branch would suggest that an appropriate conceptual framework of reporting, for example in the Kenyan banking sector, would be for Kenyan banks to engage in social reporting to legitimise their business activities in line with as many stakeholder groups' expectations as possible. 
Donaldson (1999; p. 237) suggests there many be enough "conceptual glue" to converge these two branches of stakeholder theory. Donaldson and Preston (1995; p. 66) aver that there remains the possibility that the different branches of stakeholder theory are "mutually supportive". In light of the potential merging of these theoretical branches as one, this paper adopts Driver and Thompson's 2002; p. 114) sense of stakeholding with its many laden meanings as "the sense of strengthening the company".

In considering the extent and explanation of Kenyan banks' disclosure of corporate social information in annual reports it is salient to address the issue of disclosures in the twin contexts of banks and developing countries. Until recently, the banking sector has generally been considered to have little social and environmental impact (Elkington, 1994). However, this perception is changing dramatically, essentially because of the sectors vital role in economic development and sustainability. In this respect, Moyo and Rohan (2006) states:

The financial services sector plays a critical role in promoting sustainable development through its financial intermediation. Increasingly, the process of financing business activities is being seen as a way to stimulate the business sector to control its broader environmental, social and economic impacts (p.289).

Hence to conform to the society's expectation banks must integrate environmental and social impacts as part of core investment risk evaluations and therefore, influence a number of related institutions. 
Few studies examined corporate social reporting in the banking industry. Douglas, Doris and Johnson (2004) studied corporate social reporting in the annual reports, and on the web sites of six Irish financial institutions. Their findings suggest that the quantity and quality of social information disclosed is far less than leading European banks. They also observed that greater amount of information is provided on the website than in the annual report. They attribute low disclosure of social information to voluntary nature of the reporting regime in Ireland.

Although CSR research has been the subject of immense study for the past few decades, the empirical studies dealt mainly with the developed Western economies (Tsang, 1998). A small body of empirical studies is emerging among a number of developing countries. For example, in a recent study, Ratanajongkol, Harvey and Low (2006) examined corporate social reporting in Thailand. They examined the extent and nature of corporate social reporting of 40 Thai companies over 3 year period. Overall, they found that the level of corporate social reporting is increasing, with Thai companies reporting more on human resources.

A number of prior studies have examined determinants of corporate disclosure practices. These studies can be split broadly into two categories, namely, mandatory and voluntary. Mandatory disclosure research mainly concerns compliance with as well as comprehensiveness of disclosure of 
statutory disclosure requirements (Ahmed \& Nicholls, 1994, Owusu-Ansah, 1998, Wallace, Naser, \& Mora, 1994). Voluntary disclosure studies deals with discretionary release of financial and non-financial information over and above the mandatory requirements (Chow \& Wong-Boren, 1987, Cooke, 1991, Hossain \& Adams, 1995, Hossain, Perera, \& Rahman, 1995). A prominent feature of disclosure research is concentration on the developed western economies. However, disclosure research in developing countries is growing (Ahmed \& Nicholls, 1994, Barako, Hancock, \& Izan, 2006, Belal, 2000, Chow \& Wong-Boren, 1987, Hossain, Tan, \& Adams, 1994, Owusu-Ansah, 1998, Wallace, 1988).

In recent years, voluntary disclosure studies have branched into finer, more focused research, areas such as environmental and social disclosure (Belal, 2000, Belal, 2001, Disu \& Gray, 1998, Kisenyi \& Gray, 1998), human resource (Brown, Tower, \& Taplin, 2005), intellectual capital (Williams, 2001) and corporate governance issues (Haniffa and Cooke 2002, Barako et al. 2006). The results of these studies are mixed. However, a consistent finding in previous research is that firm size is an important determinant of corporate social reporting practices. For instance, Ahmed and Courtis (1999) in a metaanalysis of 29 disclosure studies find that size, listing status and financial leverage are predictors of levels of disclosure in corporate annual reports. It is evident that different aspects of corporate governance attributes influence corporate reporting practices (Barako et al. 2006). This research draws on 
prior studies to investigate the influence of corporate governance attributes on corporate social reporting practices of Kenyan banks. Corporate governance characteristics ${ }^{3}$ examined are: independence of board (board composition), proportion of foreign nationals on the board and proportion of women on the board.

Board composition is represented by the proportion of non-executive directors to the total number of directors on the board. Non-executive directors are regarded as a reliable mechanism capable of diffusing agency conflicts between managers and owners (Fama \& Jensen, 1983b). They are viewed as providing the necessary checks and balances needed to enhance board effectiveness (Franks, Mayer, \& Renneboog, 2001). Prior research studies present empirical evidence of the relationship between proportion of non-executive directors on board and the level of voluntary disclosure (Chen \& Jaggi, 2000, Eng \& Mak, 2003, Haniffa \& Cooke, 2002). Thus, consistent with past findings, the following hypothesis is tested:

H1: The higher the proportion of non-executive directors, the higher the level of voluntary disclosure of corporate social reporting information.

In recent years board diversity has become a critical component of corporate governance structure. The theme of board diversity fits well into the framework of stakeholder theory. Carter, Simkins and Simpson (2003) argue in favour of board diversity that "[it] increases board independence because with a different gender, ethnicity, or cultural background might ask questions

${ }^{3}$ Central Bank of Kenya requires all banks to separate the position and role of board chair and CEO, as well as establish board audit committee. Thus, due to the statutory requirements, variables such as board audit committee and board leadership structure are not considered in this study. 
that would not come from directors with more traditional backgrounds" (p.37). Carter et al. (2003) present empirical evidence of a significant positive relationship between board diversity, defined as percentage of women, African American, Asians, and Hispanics on board of directors and firm value. In addition, prior research indicates that board diversity, as measured by the presence of women directors, is associated with stronger orientation toward corporate social reporting (Ibrahim \& Angelidis, 1994), and higher levels of social performance (Siciliano, 1996). Recruiting more women to corporate boards may bring about diversity of opinions and perspectives to board discussions. For example, a woman director summarised the importance of women on a company board as follows:

Women have a different perspective and I think as a group they have a different set of skills. If you are putting a team together then you need a team which has a wide base of skills. By not having a true representation...then you are cutting yourself from half of the resource pool. In my experience women have had much better communication and people skill and in some ways lateral thinking skills (Shilton, McGregor, \& Tremaine, 1996).

Bilimoria and Wheeler (2000, cited in Walt \& Ingley, 2003 p. 226) further

illustrate the contribution of women on corporate board as follows:

Despite the fear cited by many CEOs that women will disrupt an otherwise cooperative boardroom climate by raising difficult women's issue in an adversarial manner as a reason for not hiring women directors, and despite women directors' own consciousness of being perceived as a having a women's agenda or being single-issue woman, these women recognise their responsibility to address issues relating to women's recruitment, retention, development and advancement in organisations and see these as appropriate business issues for board discussion (Walt \& Ingley, 2003). 
Adams and Ferreira (2004; p. 3) suggest that boards with a higher proportion of women directors have more board meetings and different attendance patterns at board meetings which make diverse boards more effective than homogenous boards. Adams and Ferreira (2004; p. 11) argue that "women are intrinsically more "stabilizing" than men. In terms of gender-related boardroom dynamics, Huse and Solberg (2006) concluded that women could contribute to boards by creating alliances, preparing and involving themselves in board matters, attending the important decision-making arenas and being visible.

In terms of disclosures made by a board with foreign nationals, Wallace \& Naser (1995) did not find a significant relationship between disclosure levels and boards dominated by directors of non-Chinese background, Haniffa and Cooke (2002) document empirical evidence of the positive association between the proportion of Malay directors on the board and the extent of voluntary disclosure by Malaysian companies. In a country with two distinct ethnic groups: Malay and Chinese, their finding suggests that ethnic orientation impacts on firms' corporate reporting practices.

The association between the proportion of foreign nationals and disclosures in the prior litertature raises the issue of causality. Causality of board diversity was considered by Fields and Keys (2003) who found that heterogeneity of experiences, ideas and innovations that individuals bring to a company 
impacts on company performance. Erhandt, Werbel and Shrader (2003) argue that ethnic representation on boards increases firm financial performance, while Ayuso and Argandona (2007) argue that women and foreign directors are usually assumed to play an important role in favouring corporate social reporting strategies. In line with these arguments, this paper argues that it is likely that board diversity measured as percentage of women and foreign national (non-Kenyans) on the board of directors may influence corporate reporting behaviour of banks. Hence, the following hypotheses are examined:

H2: The higher the proportion of women directors on the board, the higher the level of voluntary disclosure of corporate social reporting information.

H3: The higher the proportion of foreign nationals on the board, the higher the level of voluntary disclosure of corporate social reporting information.

Non-performing loan ratio is included as a control variable as nonperforming loans are a fundamental aspect of the banking sector which is central to this study's research question. Credit risk, is arguably, the most critical risk factor in the Kenyan financial sector with a huge level of nonperforming loans. The Kenyan Government has been exploring ways to alleviate this problem. In this respect, a local daily newspaper reports on Kenyan government initiative as follows “...mandated the Central Bank of Kenya to explore the feasibility of forming a Non-Performing Loans Agency to help clean up bank balance sheets..." (Mburu, 2003). In addition, as per 
Central Bank of Kenya guidelines, bank board of directors are required to develop and approve credit risk policy ${ }^{4}$.

\section{$4 \quad$ Research Design}

This section explains source of the data, measurement of the dependent variable and operational definition of independent variables.

\section{Data Source}

An annual report of banks is the primary source of data for this research. The entire population of 40 Kenyan banks is included in the sample 5 .

\section{Dependent Variable}

This research uses a corporate social reporting disclosure index to measure the extent of voluntary disclosure. The list of the disclosure items are drawn from past corporate social disclosure studies. The index however, is crafted to suit social issues that are pertinent to the Kenyan environment, such as combating the HIV/ AIDS.

A binary coding technique is used, with a score of 1 if an item is disclosed and 0 if not. This is consistent with prior disclosure scoring approach (Cooke, 1991, Cooke, 1992, Hossain, Perera, \& Rahman, 1995). The unweighted

\footnotetext{
${ }^{4}$ With respect to board oversight role, the Central Bank of Kenya risk management guidelines reads; “The board of directors carries the ultimate responsibility of approving and reviewing the credit risk strategy and credit risk policies of the bank. This role is part of the board's ultimate responsibility of offering overall strategic direction of the bank"(p. 13).

${ }^{5}$ While a total of 40 banks in the sample may appear low, they do represent the entire population facilitating the ease with which to make conclusions about the data.
} 
disclosure index has the advantage of reducing subjectivity in assigning weights to the disclosure items. To get a company's score, the scores for each item are added and the total is divided by the maximum possible score, and multiplied by a hundred to gather the percentage scores. In this study, the number of disclosure items is 22 which represents the maximum possible disclosure score. Thus, for example, if a bank discloses 11 out of 22 items, the score for the dependent variable is $50 \%$. The average score is calculated by dividing the number of banks disclosing a particular item by the total number of items. Consistent with previous studies (Barako et al, 2006), all items are equally weighted.

\section{Independent Variables}

The corporate governance variables examined in this study are: board composition (independence of board), gender representation on board, foreign nationals on board and non-performing loan ratio, which is a control variable. Table 1 presents a summary of the operational definition of these predictor variables. The independent variable of ratio of non-executive directors on board is represented by the ratio of non-executive directors to the total number of directors on the board. The independent variable of women representation on the board is the ratio of the number of women directors to the total number of directors on the board. The independent variable of foreign nationals on boards is the ration of non-Kenyan directors to the total number of directors on the board. A necessary limitation of this study is that 
it does not delineate the countries these foreign directors come from. Another necessary limitation of this study is that it does not consider the number of board members or other ownership variables. While they are of interest to this study, addition of such variables is limited by the small sample size of the data set.

The board composition is comprised of executive and non-executive directors.

\section{Table 1. Operational definition of independent variables}

\begin{tabular}{|c|c|c|}
\hline Independent variables & Operational definition & Source of information \\
\hline $\begin{array}{l}\text { Ratio of non-executive } \\
\text { directors on board }\end{array}$ & $\begin{array}{l}\text { Ratio of non-executive } \\
\text { directors to total number of } \\
\text { directors on the board }\end{array}$ & Banks' annual report \\
\hline $\begin{array}{l}\text { Women representation on } \\
\text { board }\end{array}$ & $\begin{array}{l}\text { Ratio of women directors to } \\
\text { total number of directors } \\
\text { on the board }\end{array}$ & Banks' annual reports \\
\hline Foreign national on boards & $\begin{array}{l}\text { Ratio of non-Kenyan } \\
\text { directors to total number of } \\
\text { directors on the board }\end{array}$ & Banks' annual reports \\
\hline \multicolumn{3}{|l|}{ Control variable } \\
\hline Non-performing loan ratio & $\begin{array}{l}\text { Ratio of Non-performing } \\
\text { loan to total loans }\end{array}$ & $\begin{array}{l}\text { Central Bank Supervision } \\
\text { report }\end{array}$ \\
\hline
\end{tabular}

\section{$5 \quad$ Results}

Descriptive Statistics

Descriptive statistics of the explanatory variables are contained in Table 2. Board composition which is measured by the proportion of non-executive directors to total number of directors indicates that most banks have a majority of non-executive directors on the board with a mean of $59 \%$. 
However, some financial institutions are dominated by executive directors. Non-performing loan ratio indicates great disparities among financial institutions with a low of $1.6 \%$ and a high of $83.2 \%$.

Table 2. Descriptive statistics of predictor variables

\begin{tabular}{|c|c|c|c|c|}
\hline Panel A. Variables & $\begin{array}{c}\text { Mean } \\
\%\end{array}$ & $\underset{\% \%}{\operatorname{Minimum}}$ & $\begin{array}{l}\text { Maximum } \\
\%\end{array}$ & $\begin{array}{c}\text { Standard } \\
\text { Deviation }\end{array}$ \\
\hline Independence of Board & 58.70 & 0.00 & 91.7 & 24.44 \\
\hline $\begin{array}{l}\text { Gender representation on } \\
\text { board }\end{array}$ & 4.18 & 0.00 & 27.30 & 8.18 \\
\hline Foreign national on boards & 22.52 & 0.00 & 100.00 & 29.76 \\
\hline Non-performing loan ratio & 20.07 & 1.60 & 83.20 & 18.52 \\
\hline $\begin{array}{l}\text { Panel B. Gender } \\
\text { Representation }\end{array}$ & $\begin{array}{c}\text { \# of } \\
\text { banks }\end{array}$ & $\%$ of banks & & \\
\hline No women on board & 30 & 75.00 & & \\
\hline 1 woman on board & 5 & 12.50 & & \\
\hline 2 women on board & 3 & 7.50 & & \\
\hline 3 women on board & 2 & 5.00 & & \\
\hline $\begin{array}{l}\text { More than } 3 \text { women on } \\
\text { board }\end{array}$ & 0 & 0.00 & & \\
\hline Total & 40 & 100.00 & & \\
\hline
\end{tabular}

On average the ratio of foreign directors on bank boards is $23 \%$. Though a minority, some banks, mostly foreign owned financial institutions have boards comprised entirely of foreign nationals.

The highest percentage of women representation on bank boards is $27 \%$ with a mean of only $4 \%$. A further analysis in Panel B of Table 3 presents a clear picture. $75 \%$ of Kenyan banks have no women on their boards, with only two banks (constituting $5 \%$ of the sample population) having at least three women on their Board of Directors. Gender representation on boards of Kenyan banks reflects the global concerns of low women representation on corporate 
boards. For example, Thomas (2001) undertaking an empirical longitudinal study of women representation on the boards of British retailing companies concludes that men not only dominate board membership but also key positions of Board chair and Chief Executive.

In Australia, Korn/Ferry International (Burgess \& Tharenou, 2002) note that most of the top 20 companies had at least one woman on the board. Overall, the number of women represented on boards is very low. Moreover, there is no difference in results whether there are one, two or three women on the board, and these women are usually professionally-oriented. In Canada, Burke (1993) observes that 5 percent of board members are women. Kesner (Burke, 1993) examine the 250 largest companies in the US with a total of 3128 board members, and concludes that 3.6 (113) percent are women. Brennan \& McCafferty (1997) finds that women comprise $4.3 \%$ of total directors of the Irish public and semi-state owned enterprises. Similarly, Pajo, McGregory \& Cleland (1997), notes that women constitute only $4.4 \%$ of the total number of directors of the top 200 New Zealand companies.

Table 4 contain list of items included in the corporate social disclosure index. Consistent with the overall low mean disclosure score of $15 \%$, it is clearly evident that banks disclose very limited social information in the annual report. In particular, no banks disclosure recruitments, employment of special groups, assistance to retiring employees, employees productivity and turnover. In addition, very few banks, $12.50 \%$ and $0.03 \%$ respectively disclose information relating to environment policy and environmental activities they 
undertake, while only 3 banks contribute to the national AIDS campaign.

Overall, Table 3 highlights the extreme low levels of important attached to social information reporting by banks.

\section{Table 3. List of social disclosure items}

\begin{tabular}{|c|c|c|}
\hline Social disclosures index & $\begin{array}{l}\text { \#. of Banks } \\
\text { disclosing }\end{array}$ & $\%$ \\
\hline $\begin{array}{l}\text { 1. Donation of cash, products and employees service to } \\
\text { support community programs }\end{array}$ & 15 & 37.5 \\
\hline 2. Contribution towards national AIDS campaign & 3 & 9.37 \\
\hline 3. Support for staff affected by AIDS & 3 & 9.37 \\
\hline 4. Employees' appreciation & 27 & 84.37 \\
\hline 5. Discussion of employees' welfare & 5 & 15.63 \\
\hline 6. Sponsorship of public health program/activities & 4 & 12.50 \\
\hline 7. Policy on employees' training & 8 & 25.00 \\
\hline 8. Nature of training & 3 & 9.37 \\
\hline 9. Recruitment challenges & 0 & 0.00 \\
\hline 10. Funding scholarship program & 6 & 18.75 \\
\hline $\begin{array}{l}\text { 11. Contribution towards national problems/issues } \\
\text { e.g. famine relief, people affected by wars }\end{array}$ & 8 & 25.00 \\
\hline 12. Corporate environmental policy & 4 & 12.50 \\
\hline 13. Environmental projects/activities undertaken & 1 & 0.03 \\
\hline $\begin{array}{l}\text { 14. Employment of special groups e.g. the } \\
\text { handicapped }\end{array}$ & 0 & 0.00 \\
\hline $\begin{array}{l}\text { 15. Assistance and guidance to retiring employees or } \\
\text { those declared redundant }\end{array}$ & 0 & 0.00 \\
\hline $\begin{array}{l}\text { 16. Establishment of employee share purchase } \\
\text { scheme }\end{array}$ & 1 & 0.03 \\
\hline 17. Providing qualifications of employees recruited & 3 & 9.37 \\
\hline $\begin{array}{l}\text { 18. Providing statistics per employee e.g. asset per } \\
\text { employee, sales per employee. }\end{array}$ & 0 & 0.00 \\
\hline 19. Information and statistics on employee turnover & 0 & 0.00 \\
\hline 20. Supporting nation pride e.g. sponsorship of the & 1 & 0.03 \\
\hline
\end{tabular}




\begin{tabular}{|c|c|c|}
\hline Olympic team, the national soccer team. & & \\
\hline 21. Part-time of employment of students & 0 & 0.00 \\
\hline 22. Statement of corporate social responsibility & 1 & 0.03 \\
\hline AVERAGE & & $15 \%$ \\
\hline
\end{tabular}

Table 4 present the Pearson correlations between the study's variables.

Disclosure of corporate social information is positively associated with proportion of women on the board, consistent with the hypothesis. The significant correlation coefficient of $0.410(\mathrm{p}<0.001)$ provides some evidence of a univariate relationship between disclosure of corporate social information and representation of women on the board. Although Pearson correlations show a negative correlation coefficients of 0.520 , this correlation value is well below the critical limits of 0.80 (Hair, Anderson, Tatham and Black 1995), and it is suggested that a multicollinearity problem between these independent variables is not a serious concern.

This result supports the need to undertake a more powerful statistical analysis to reveal predictors of voluntary corporate social reporting disclosure. In the following section results of multiple regression analysis are discussed.

Table 4. Pearson correlation matrix

\begin{tabular}{llllll}
\hline & SDscore & $\begin{array}{l}\text { Board } \\
\text { composition }\end{array}$ & $\begin{array}{l}\text { Foreigners on } \\
\text { Board }\end{array}$ & $\begin{array}{l}\text { Women } \\
\text { on Board }\end{array}$ & $\begin{array}{l}\text { Non- } \\
\text { performing } \\
\text { loan ratio }\end{array}$ \\
\hline Board composition & 0.272 & & & \\
$\begin{array}{l}\text { Foreigners on Board } \\
\text { Women on Board }\end{array}$ & 0.057 & $-0.520^{* *}$ & & \\
Non-performing loan ratio & $0.410^{* *}$ & 0.184 & -0.187 & & \\
& -0.221 & 0.178 & $-0.383^{*}$ & -0.063 & 1.00 \\
\hline
\end{tabular}

${ }^{*} \mathrm{p}<0.01$, two-tailed, ${ }^{* *} \mathrm{p}<0.05$, two-tailed 
Multiple Regression Analysis

Multiple regression is used to examine the relationship between the dependent variable described as the level of disclosure of social information and the three corporate governance variables. The results of the regression model are provided in Table 5.

\section{TABLE 5. Multiple regression analysis}

\begin{tabular}{lcccc}
\hline Independent Variables & Predicted sign & $\begin{array}{c}\text { Standardised } \\
\text { Coefficient }\end{array}$ & P-value & VIF6 \\
\hline Test Variables & + & 0.463 & $0.010^{*}$ & 1.421 \\
Board composition & + & 0.499 & $0.002^{* *}$ & 1.046 \\
Women on Board & + & 0.308 & 0.099 & 1.652 \\
Foreigners on Board & & -0.253 & 0.108 & 1.175 \\
Non-performing loan ratio & $47.0 \%$ & & & \\
R-square & $39.1 \%$ & & & \\
Adjusted R-square & 0.001 & & \\
Sig. F & & & \\
N= 40 & Legend: ** highly significant; * significant & & \\
\hline Legen & &
\end{tabular}

The board composition variable is significantly $(p<0.05)$ associated with the extent of social information disclosed in the banks annual reports. The higher the number of independent members on the bank board, the higher the level of social information reported in the annual report. This finding supports positive association predicted in $\mathrm{H} 1$. This result is consistent with the findings of prior disclosure research (for example, Haniffa and Cooke 2002, Chen and Jaggi 2000) and empirically verifies the influence of non-executive directors

\footnotetext{
${ }^{6}$ A basic approach to detecting collinearity problem is visual inspection of correlation matrix of the explanatory variables. Correlation coefficient is considered harmful if it exceeded 0.8 (Farrar \& Glauber 1967; Studenmund 1992). A more rigourous and diagnostic method widely used is the Variance Inflation Factor (VIF) for each of the independent variable (Madalla, 1992). According to Neter \& Kutner (1989) collinearity is considered a problem if the VIF exceeds 10. Thus, based on correlation matrix and VIF multicollinearity is not likely to influence the regression analysis, since the highest VIF of 2.06 is far less than the threshold of 10 .
} 
on corporate reporting practices. In the Kenyan context, the finding reflects the recent corporate reforms emphasis on the role of non-executive directors on company boards (Barako et al. 2006) ${ }^{7}$.

The results in Table 5 indicates that the board gender diversity variable is statistically significant $(\mathrm{p}<0.05)$ predictor and therefore $\mathrm{H} 2$ is supported. Thus, women representation on board is significantly positively associated with the extent of corporate social reporting information disclosed in the banks annual report. This result is consistent with earlier studies that document empirical evidence that presence of women directors is associated with stronger orientation toward corporate social reporting (Ibrahim \& Angelidis, 1994), and higher levels of corporate social reporting (Siciliano, 1996).

The proportion of foreign national on the board of banks is not significantly associated with the level of voluntary disclosure. This finding is consistent with prior research by Wallace and Naser (1995) study of boards dominated by directors of non-Chinese (foreigners) background and the level of disclosure by Hong Kong listed companies. Foreign nationals on bank boards often represent interests of foreign owners, thus their very presence on board may act as substitute for enhanced disclosure. The control variable, non-

\footnotetext{
${ }^{7}$ As one referee points out, ostensibly while it appears greater disclosure occurs with more non-executive directors, it is possible that executive bank directors who give more posts to non-executive directors influence may actually be the ones influencing the levels of disclosures. Further research, particularly through a qualitative paradigm, may shed light on this possibility.
} 
performing loan ratio is not a significant predictor of the level of social information disclosed in the annual report.

\section{Summary and Implications}

This study examines the influence of corporate governance attributes on the level of social information disclosed in banks annual report. It makes three important contributions to corporate disclosure research. First, it extends prior research to the banking industry, which is often excluded from sample companies due to the sector's more stringent regulatory regime. Second, it adds to the limited number of studies that have examined disclosure practices in a developing country. Third, it highlights the importance of women board representation to improve business communication.

Overall, the level of disclosure of social information disclosed by Kenyan banks is very low with a mean of $15 \%$. In particular, banks do not disclose important information relating to recruitments, employment of special groups, assistance to retiring employees, employees productivity and turnover. In addition, very few banks, $12.50 \%$ and $0.03 \%$ respectively disclose information relating to environment policy and environmental activities they undertake, while only 3 banks contribute to the national AIDS campaign. The low level of communication on social issues in a sector that has profound effect on the society through its intermediation role is troubling, since past poor performance in the banking sector is attributed to weak disclosure 
practices. Kenyan banks appear to discern little expectation of the 'social contract' between banks and society as suggested by legitimacy theory, and surprisingly little weight to the voices of financial stakeholder (who in this enlightened age may see environmental and social impacts as part of core investment risk evaluations) as inferred by the managerial branch of stakeholder theory. But, of course, what is most disappointing about the weak disclosure practices of Kenyan banks, when the ethical branch of stakeholder theory is evoked, is that the voices of all stakeholders, regardless of how distant or close they are to banks, are given short shrift. Earlier, this study noted the difficulty businesses face in satisfying the different needs of stakeholders but the results of the study show that on a wide ranging set of corporate social reporting criteria Kenyan banks disclosures are very low.

While social reporting is purely voluntary in the Kenyan context, the low level of disclosure in the banks annual report suggests that the sector makes little contributes in terms of the general societal well being. This particularly evident, for instance none of the banks report issue relating to employment of disadvantaged members in the community such as the handicapped or even retirees. In addition, very few banks take part in the national HIV/AIDS campaign, an epidemic that is having dramatic effect on Kenyan economy. Since the concept corporate social responsibility is becoming a global phenomena, the banking sector in Kenya may have to do more, and equally important disclose their contribution to social and environmental matters. 
Results of multiple regression analysis indicate that board gender diversity defined as ratio of women directors on a board to total number of directors is significant determinant of the level of social information disclosed by banks in annual reports. This result is consistent with prior finding that board gender diversity enhances firm value (Carter et al. 2003). Thus, it is in the best interest of banks that qualified and competent women are co-opted onto bank boards to realise benefits related to such diversity of the board. The findings show that increased women's representation at the Board level will significantly and positively influence corporate communication. In addition, it is important to note, compared to the past few decades the educational gender disparity is less, with more women enrolling and qualifying with degree and postgraduate qualifications. Clearly, better communication is obtainable in the future.

Ratio of non-executive directors on board measured as proportion of nonexecutive directors to total number of the board members is positively associated with the extent of information disclosed. The Central Bank of Kenya, consistent with international practices, in the past few years has been encouraging banks to have more non-executive directors on boards. The empirical evidence supports this reform measure. 


\section{References}

Adams, R. B. and Ferreira, D. (2004) Gender Diversity in the Boardroom, European Corporate Governance Institute, Finance Working Paper No 57.

African Peer Review Mechanism. 2006. Country Review Report of the Republic of Kenya.

Ahmed, K. \& D. Nicholls. 1994. The impact of non-financial company characteristics on mandatory disclosure compliance in developing countries: The case of Bangladesh. The International Journal of Accounting, 29(1): 62-77.

Ayuso, S. and Argandona, A. 2007. Responsible Corporate Governance: Towards A Stakeholder Board of Directors? IESE Business School Working Paper No. 701, July.

Barako, D. G., P. Hancock, \& H. Y. Izan. 2006. Factors Influencing voluntary corporate disclosure by Kenyan companies. Corporate Governance: An International Review, 14(2): 107 - 25.

Belal, A. R. 2000. Environmental reporting in developing countries: Empirical evidence from Bangladesh. Eco-Management and Auditing, 7(4): 114 - 21.

Belal, A. R. 2001. A study of corporate social disclosure in Bangladesh. Managerial Auditing Journal, 16(5): 274-89.

Brennan, N. \& J. McCafferty. 1997. Corporate governance practices in Irish companies. Irish Business and Administrative Research, 18: 116-35.

Brown, A. M., G. Tower, \& R. Taplin. 2005. Human resources disclosure in the annual reports of Pacific Island countries. Asia Pacific Journal of Human Resources, 43: 252 - 72.

Brown, A. M., Purushothaman, M., Scharl, A. and Astami, E. W. (2007), Natural

Environmental Disclosures in Pacific Island Countries: Analysing the Public

Communication of South Pacific Exchange (SPSE) Entities, The Journal of

Accounting, Management and Economics Research, February., Vol.7, No. 1, pp.47-

68.

Burgess, Z. \& P. Tharenou. 2002. Women board directors: Characteristics of the few. Journal of Business Ethics, 37(1): 39-49.

Burke, R. J. 1993. Women on corporate boards of directors. Equal opportunities international, 12(6): 5-13.

Carter, D. A., B. J. Simkins, \& W. G. Simpson. 2003. Corporate governance, board diversity and firm value. The Financial Review, 38: 33 - 53.

Chen, C. J. P. \& B. Jaggi. 2000. Association between independent non-executive directors, family control and financial disclosures in Hong Kong. Journal of Accounting and Public Policy, 19(4-5): 285-310.

Chow, C. W. \& A. Wong-Boren. 1987. Voluntary financial disclosure by Mexican corporations. The Accounting Review, 62(3): 533-41. 
Cooke, T. E. 1991. An assessment of voluntary disclosure in the annual reports of Japanese corporations. The International Journal of Accounting, 26: 174-89.

Cooke, T. E. 1992. The impact of size, stock market listing and industry type on disclosure in the annual reports of Japanese listed corporations. Accounting and Business Research, 22(87): 229-37.

Deegan, C. 2000. Financial Accounting Theory. Sydney: McGraw Hill.

Deegan, C., M. Rankin, \& P. Voght. 2000. Firms' disclosure reactions to major social incidents: Australian evidence Accounting Forum, 24(1): 101-30.

Disu, A. \& R. H. Gray. 1998. An exploration of social reporting and MNCs in Nigeria. Social and Environmental Accounting, 18(2): 13-15.

Donaldson, T. 1999. Making stakeholder theory whole, Academy of Management Review, 24(2): 237-241.

Donaldson, T. and L.E. Preston (1995). The stakeholder theory of the corporation: concepts, evidence, and implications, Academy of management Review, 20(1): 65-91. Douglas, A., J. Doris, \& B. Johnson. 2004. Corporate social reporting in Irish financial institutions. The TQM Magazine, 16(6): 387-95.

Driver, C. and Thompson, G. (2002). Corporate Governance and Democracy, Journal of Management and Governance, May, 6(2): 111-130.

Elkington, J. 1994. Towards the sustainable corporation win-win-win business strategies for sustainable development. California Management Review, 36(2): 90100.

Eng, L. L. \& Y. T. Mak. 2003. Corporate governance and voluntary disclosure. Journal of Accounting and Public Policy, 22: 325 - 45.

Erhandt, N. L., Werbel, J.D. and Shrader, C.B. 2003, Board of Director Diversity and Firm Financial Performance, Corporate Governance: An International Review, 11(2) : 102-111.

Fama, E. F. \& M. C. Jensen. 1983b. Agency problem and residual claims. The Journal of Law and Economics, 1983(26): 327-49.

Fields, M. A. and Keys, P. Y. (2003) The Emergence of Corporate Governance from Wall St. to Main St.: Outside Directors, Board Diversity, Earnings Management, and Managerial Incentives to Bear Risk, The Financial Review, 38: 1-24.

Franks, J., C. Mayer, \& L. Renneboog. 2001. Who discipline management in poorly performing companies. Journal of Financial Intermediation, 10: 209-48.

Hair, JF, Anderson, RE, Tatham, RL and Black, WC 1995, Multivariate data analysis, Fourth edn, Prentice-Hall, Inc. NJ, USA.

Haniffa, R. M. \& T. E. Cooke. 2002. Culture, corporate governance and disclosure in Malaysian corporations. Abacus, 38(3): 317-49.

Higgs, D. 2003. Review of the Role and Effectiveness of Non-Executive Directors, http://www.dti.gov.uk/cld/non_execs_review

Hossain, M. \& M. Adams. 1995. Voluntary financial disclosure by Australian listed companies. Australian Accounting Review, 5(2): 45-55.

Hossain, M., M. H. B. Perera, \& A. R. Rahman. 1995. Voluntary disclosure in the annual reports of New Zealand companies. Journal of International Financial Management and Accounting, 6(1): 69-87.

Hossain, M., L. M. Tan, \& M. Adams. 1994. Voluntary disclosure in an emerging capital market: Some empirical evidence from companies listed on Kuala Lumpur stock exchange. The International Journal of Accounting, 29(4): 334-51.

Huse, M. \& Solberg, A. G. (2006). Gender-related boardroom dynamics: How Scandinavian women make and can make contributions on corporate boards, Women in Management Review, 21(2): 113-130. 
Ibrahim, N. A. \& J. P. Angelidis. 1994. Effect of board members' gender on corporate social responsiveness orientation. Journal of Applied Business Research, 10(1): 3541.

Ismail, K. N. \& R. Chandler. 2005. Disclosure in the quarterly reports of Malaysian companies. Financial Reporting, Regulation and Governance, 4(1): 1 - 26.

Khalid, A. 2005. The association between firm-specific characteristics and disclosure: The case of Saudi Arabia. The Journal of American Academy of Business, 7(1): 2005.

Kisenyi, V. \& R. H. Gray. 1998. Social disclosure in Uganda. Social and Environmental Accounting, 18(2): 16-18.

Leung, S. \& B. Horwitz. 2004. Director ownership and voluntary segment disclosure: Hong Kong evidence Journal of International Financial Management and Accounting, 15(3).

Moyo, T. \& S. Rohan. 2006. Corporate citizenship in the context of the financial services sector: what lessons from the Financial Sector Charter? Development Southern Africa, 23(2): 289-303.

O'Dwyer, B. 2002. Managerial perceptions of corporate social disclosure: An Irish stories. Accounting, Auditing and Accountability Journal, 15(3): 406-36.

Owusu-Ansah, S. 1998. The impact of corporate attributes on the extent of mandatory disclosure and reporting by listed companies in Zimbabwe. The International Journal of Accounting, 33(5): 605-31.

Pajo, K., J. McGregor, \& J. Cleland. 1997. Profiling the pioneers: Women directors on New Zealand corporate boards. Women in Management Review, 12(5): 174 - 81.

Ratanajongkol, S., H. Davey, \& M. Low. 2006. Corporate social reporting in Thailand: The news is all good and increasing. Qualitative research in Accounting and Management, 3(1): 67-83.

Shilton, J., J. McGregor, \& M. Tremaine. 1996. Feminizing the board: A study of the effect of corporatization on the number and status of women directors in New Zealand companies. Women in Management Review, 11(3): 20-30.

Siciliano, J. I. 1996. The relationship of board member disversity and organisation performance. Journal of Business Ethics, 15(12): 1313-20.

The Centre for Corporate Governance. 2005. Guidelines on reporting and disclosure in Kenya.

The Centre for Corporate Governance. 2004. A study of corporate governance practices in the commercial banking sector in Kenya.

Thomas, B. 2001. Women at the top in British retailing: A longitudinal analysis. The Service Industries Journal, 21(3): 1-12.

Tsang, E. W. K. 1998. A longitudinal study of corporate social reporting in Singapore: The case of the banking, food and beverages and hotel industries. Accounting, Auditing and Accountability Journal, 11(3): 624-35.

Wallace, R. S. O. 1988. Corporate financial reporting in Nigeria. Accounting and Business Research, 18(72): 352-62.

Wallace, R. S. O. \& K. Naser. 1995. Firm-specific determinants of comprehensiveness of mandatory disclosure in the corporate annual reports of firms on the stock exchange of Hong Kong. Journal of Accounting and Public Policy, 14(4): 311-68.

Wallace, R. S. O., K. Naser, \& A. Mora. 1994. The relationship between the comprehensiveness of corporate annual reports and firm specific characteristics in Spain. Accounting and Business Research, 25(97): 41-53. 
Walt, N. \& Ingley, C. 2003. Board dynamics and the influence of Professional background, gender and ethnic diversity of directors. Corporate Governance: An International Review, 11(3): 218 - 234.

Williams, S. M. 2001. Is intellectual capital performance and disclosure practices related? Journal of Intellectual Capital, 2(3): 192-203. 